\title{
Research assistants' perception of mistreatment and the strategies they prefer to overcome this mistreatment ${ }^{1}$
}

\author{
Gizem Günçavdı \\ Soner Polat $^{3}$
}

\begin{abstract}
The purpose of this study is to determine research assistants' perception of mistreatment from other faculty members and the strategies they prefer to overcome this mistreatment. The sample of this study includes 255 research assistants who work at seven faculties at Kocaeli University, Turkey during the academic year 2014-2015. Within this study, it is aimed to reach the entire sample, so there is not any sample selection method used. This study is in the descriptive survey model. The data were gathered through a questionnaire which included questions about demographic information, "Mistreatment Scale" developed by Harlos and Axelrod and adapted to Turkish by Günçavdı and Polat in order to measure research assistants' perception of mistreatment; and "Secondary Appraisal Scale" developed by Rogers in order to measure strategies which research assistants prefer to overcome this mistreatment. The data were collected within a academic term. It has been found out that research assistants' perception of mistreatment from faculty showed significant difference depending on personal and organizational variables. Also it has been found out that research assistants used "barriers" strategies mostly to overcome mistreatment. This research has given an idea about research assistants' experiences about being exposed to mistreatment. According to the results of this study, it can be said that the implementers should be careful about and sensitive to gender differences, some standards can be determined for different faculties, and for departments, the administrators should be open to hear complaints and grievance, and they should try to find ways to solve things. However, this study is limited to research assistants at Kocaeli University and quantitative data. In the future researches, the samples can be extended by taking research assistants who work at other universities as the sample, and qualitative data can be gathered to interpret the results more efficiently and validly.
\end{abstract}

Keywords: mistreatment; faculty; university; research assistants; strategies

\section{Introduction}

After neo-classic theories came up, the "human" factor became important in organizations. Together with neo-classic theories, personal and social factors such as organizational communication (Balkaya\& Aykurt, 2011), motivation (Tor, 2011) and job satisfaction (Aș1k, 2010)

\footnotetext{
1 This article is the improved version of a paper presented in $1^{\text {st }}$ International Conference on Lifelong Education and Leadership for All- ICLEL 2015.

2 Research Assistant, Kocaeli University, Faculty of Education, Department of Educational Sciences, Educational Administration, Supervision, Planning and Economics, gizemguncavdi@hotmail.com

3 Associate Professor, Kocaeli University, Faculty of Education, Department of Educational Sciences, Educational Administration, Supervision, Planning and Economics, spolat@kocaeli.edu.tr
} 
Günçavd1, G., \& Polat, S. (2015). Research assistants’ perception of mistreatment and the strategies they prefer to overcome this mistreatment. International Journal of Human Sciences, 12(2), 1662-1673. doi:10.14687/ijhs.v12i2.3496

which affects the organizational productivity positively arose. However, there are some other factors which affect organizational productivity in a negative way. Mistreatment behaviours are among these factors. Mistreatment is a concept which includes negative physical and psychological interactions that occur both at personal and organizational aspects, abuse employees in terms of interactional, distributive, procedural and systematic dimensions, and affects employees' personal lives (Harlos\& Pinder, 1999; Cortina, Magley, Williams\& Langhout, 2001).

The term mistreatment was defined in different ways by different researchers (Harlos\& Pinder, 1999; Cortina, Magley, Williams\& Langhout, 2001; Harlos\& Axelrod, 2005; OlsonBuchanan\& Boswell, 2009; Penhaligon, Louis\& Restubog, 2013). Harlos and Pinder (1999) defined the concept of workplace mistreatment as behaviours that occur both at personal and organizational aspects, abuse employees in terms of interactional, distributive, procedural and systematic dimensions; Cortina and friends (2001) as negative physical and psychological interactions between individuals in an organization and affect individuals' personal lives; OlsonBuchanan and Boswell (2009) as an employee's feelings about not being treated fairly; Penhaligon and friends (2013) as damaging behaviours that affect whole organization.

Generally, workplace mistreatment is in the both interpersonal and organizational forms. Behaviours such as verbal abuse and threatening, ignoring employees' needs, not supporting employees, inappropriate physical contacts, sexual harassment, incivility, not being valued by others, preventing the opportunities to learn something new, commenting in a rude and humiliating manner, having bias towards the individual, discriminating and being ethno-centered are counted as interpersonal mistreatment (Cox, 1993; cited in Meares, Oetzel, Torres, Derkacs and Ginossar, 2004; Lim\& Cortina, 2005; Harlos\& Axelrod, 2005; Bursch, Fried, Wimmers, Cook, Baille, Zackson\& Stuber, 2013; Read\& Laschinger, 2013). Not allowing an employee to use the sources $\mathrm{s} /$ he needs to complete a work, giving too much responsibility without supplying the support needed and ignoring this situation, unfair evaluations and reward policies, organizational bias are behaviours that belong to organizational mistreatment (Cox, 1993; cited in Meares et al., 2004; Harlos\& Axelrod, 2005; Read\& Laschinger, 2013).

There are some different classifications about the concept of workplace mistreatment (Harlos\& Pinder, 1999; Harlos\& Axelrod, 2005; Blase\& Blase, 2006). Harlos and Pinder (1999) mentioned that the most inclusive concept to understand workplace mistreatment is organizational injustice. Similarly, the concept of mistreatment is used interchangeably with the concept of injustice (Boroff\& Lewin, 1997; Boswell\& Olson-Buchanan, 2004). Harlos and Pinder (1999) divided the concept of injustice into four dimensions. The first of these dimensions is interactional 
Günçavd1, G., \& Polat, S. (2015). Research assistants’ perception of mistreatment and the strategies they prefer to overcome this mistreatment. International Journal of Human Sciences, 12(2), 1662-1673. doi:10.14687/ijhs.v12i2.3496

injustice which means mistreatment applied by an authority. The second dimension is distributive injustice which is about the perception of distributing sources of the organization fairly. The third one is procedural injustice, and it includes the unfair policies that affect the decision-making process for distributing sources and the decision-making process itself. The fourth and the last dimension is systematic injustice that includes the unfair and systematically continuing situations in big organizations. It is possible to talk about four basic implementation and policy. These are discrimination, over-working, inconsistency and quitting. Another classification about mistreatment was made by Harlos and Axelrod (2005) and this mistreatment classification is used in this research. According to this classification, the dimensions of mistreatment are verbal abuse, work obstruction and emotional neglect. Harlos and Axelrod (2005) explained that the dimension of verbal abuse can be named as interpersonal mistreatment, and the dimensions of work obstruction and emotional neglect as organizational mistreatment. Depending on another classification of mistreatment, these behaviours are divided into three categories which are verbal, non-verbal and physical behaviours (Blase\& Blase, 2006; Blase et al., 2009). Among verbal behaviours, there are threatens, humiliating in public, psychological burst-outs, threatening about firing, criticising without having any basis, spreading wrong rumours, making unfair evaluations about individual's professional or personal life, isolating, discrimination, sending unreasonable condemns. Glaring, humiliating, threatening quietly, sexual harassment and pointing can be counted as non-verbal behaviours. Isolating the employee, preventing the employee from using sources and damaging his/her belongings are some examples of physical mistreatment behaviours.

Researches have put forward the reality that mistreatment can be encountered in many different organizations, from educational ones to health institutions (Cortina et al., 2001; Harlos\& Axelrod, 2005; Olson- Buchanan\& Boswell, 2009; Penhaligon, Louis\& Restubog, 2013). It has been found out that mistreatment behaviours exist at universities, one of the educational organizations, and the research assistants, who are at the lowest level in the hierarchical structure, are exposed to mistreatment (Ayan, 2011; Bayar\& Bayar, 2012; Ergöl, Koç, Eroğlu\& Taşkın, 2012).

It is known that mistreatment behaviours most probably damage organizations. Because of this fact, researches have shown that there are some strategies to overcome mistreatment that are used by employees who are exposed to mistreatment (Rogers, 1998; Blase et al., 2009; OlsonBuchanan\& Boswell, 2009; Sulea et al., 2012). One of the strategies used to overcome mistreatment is preventing these behaviours with the help of legal sanctions (Wootton, 2011). It is important to review the current the laws, correct any wrong or absence and, with the help of this, provide necessary legal sanctions to hinder employees being exposed to mistreatment. 
Günçavdı, G., \& Polat, S. (2015). Research assistants’ perception of mistreatment and the strategies they prefer to overcome this mistreatment. International Journal of Human Sciences, 12(2), 1662-1673. doi:10.14687/ijhs.v12i2.3496

Blase and friends (2009) found out that most of the teachers run from principals, talk with others about the mistreatment, endure principal's mistreatment, rationalize principal's mistreatment, watch television or listen to music at school, isolate themselves, try to see principal's good side of his/her character, complain about this situation to their friends in their personal lives and see mistreatment behaviours as a part of their job in the condition of being exposing to mistreatment in their study conducted in educational organizations. However, these behaviours are not expected as what to be done to overcome mistreatment. Blase and friends (2009) suggested principals to understand the problem of mistreatment and its devastating effects on teachers and teaching process well among the behaviours to be used to overcome mistreatment.

There is a model suggested by Rogers (1998) to be used to overcome mistreatment. This model consists of two levels, one of which is the individual's perceiving the mistreatment; and the other level is overcoming the mistreatment. The first level is called as primary appraisal, and the second level is secondary appraisal. Primary appraisal is the process during which the individual evaluates the importance of that behaviour (Lazarus\& Folkman, 1984; cited in Rogers, 1998). In this process, the individual decides whether to perceive the behaviour as mistreatment or not by thinking how that situation affects his/her wellbeing and how important that situation is for him/her. According to the model, after individual makes that decision, the second level starts. Secondary appraisal is the process during which the individual evaluates whether there is something to do to overcome the mistreatment or not (Lazarus\& Folkman, 1984; cited in Rogers, 1998). Rogers (1998) mentioned that the secondary appraisal is made up of three dimensions which are control-self, control others and barriers. The dimension of control-self is about how much control the victim has over the mistreatment. The second dimension control-other consists the victim questioning whether the other employees in organization can help him/her, and if they can whether s/he can ask help from them easily. The last dimension barriers includes the conditions that prevent the victim from being helped because of the organization's culture or climate.

Because of the fact that mistreatment behaviours are the ones that affect employees and organizational productivity negatively and so these behaviours should be prevented, strategies to be used to overcome mistreatment are important for the future of organizations. So, it is possible to say that these strategies should be taken into consideration in all kinds of organizations, and in educational organizations as well.

In the lights of the findings of other studies, the researchers purposed to search the research assistants' perceptions of mistreatment and the strategies they use to overcome this mistreatment. In this term, the main problem of this research is 'What are the research assistants' 
Günçavdı, G., \& Polat, S. (2015). Research assistants' perception of mistreatment and the strategies they prefer to overcome this mistreatment. International Journal of Human Sciences, 12(2), 1662-1673. doi:10.14687/ijhs.v12i2.3496

perception level of mistreatment and the strategies they use to overcome this?”. The sub- problems of this research are:

1. Does the research assistants' perception change depending on personal (age, tenure, gender, educational status) variables?

2. Does the research assistants' perception change depending on organizational (the faculty where they work, their study areas, the type of staff) variables?

3. What is the strategy that is used most frequently by research assistants to overcome mistreatment?

\section{Method}

\subsection{Research Model}

This research aims to define the research assistants' perception of mistreatment they are exposed to and the strategies they use to overcome these behaviours, and its model is descriptive survey model. The descriptive survey model is used to define characteristics of a specific group (Büyüköztürk, Kılıç-Çakmak, Akgün, Karadeniz\& Demirel, 2012). In other words, descriptive survey model helps researchers identify participants' views, interests, skills, attitude, etc., and this type of surveys is conducted to larger samples (Büyüköztürk et al., 2012). Fraenkel\& Wallen (2006) defined three characteristics of descriptive survey models first of which is choosing a sample from population, second of which is the data collection process' being dependant on the answers of participants, and third of which is data's being gathered from the sample, not from population.

\subsection{Participants}

The study group of this research consists of 255 research assistants who work at seven faculties in Kocaeli University Umuttepe Campus during the academic year 2014-2015. The questionnaires were sent to the research assistants, and 204 of them were returned. Six questionnaires could not be included in the analysis process because lack of information or systematic errors. As a result of this, 198 questionnaires were analyzed during the research.

Among the 198 research assistants, 105 of them were male and 93 of them were female; 76 of them worked at the Faculty of Engineering, 28 of them worked at the Faculty of Economic and Administrative Sciences (E.A.S.), 27 of them worked at the Faculty of Arts and Sciences, 15 of them worked at Faculty of Education, 15 of them worked at Faculty of Communication, 14 of them worked at the Faculty of Law, and 13 of them worked at the Faculty of Technology. 
Günçavdı, G., \& Polat, S. (2015). Research assistants' perception of mistreatment and the strategies they prefer to overcome this mistreatment. International Journal of Human Sciences, 12(2), 1662-1673. doi:10.14687/ijhs.v12i2.3496

\subsection{Data Collection Tools}

In this study, the data was gathered through a questionnaire that includes questions about demographic information (gender, age, tenure, faculty where research assistants work, educational status, study area and the type of staff), "Mistreatment Scale" and "Secondary Appraisal Scale". The data about research assistants' perception of mistreatment is measured with "Mistreatment Scale", developed by Harlos and Axelrod (2005) and adapted into Turkish by Günçavdı and Polat (2015). This scale is 5 -likert type scale ( $1=$ Never, $5=$ Always), and it has 17 items that form two dimensions. These dimensions are "interpersonal mistreatment" and "organizational mistreatment". The data about the strategies the research assistants use to overcome mistreatment was collected with a "Secondary Appraisal Scale" developed by Rogers (1998). This scale is 5-likert type scale $(1=$ Absolutely disagree, $5=$ Absolutely agree), and it has 12 items that form 3 dimensions: control-self, control others and barriers.

\subsection{Data Collection and Analysis}

Researchers used the questionnaire that was mentioned before to gather the data during this research. Before conducting the questionnaires, the necessary permission was taken from the President of Kocaeli University. After the permission was taken, the list of academic staff was downloaded from Kocaeli University's webpage, and the list of research assistants who worked at the seven faculties at Umuttepe Campus was prepared. Then the researchers found those research assistants' e-mail addresses, uploaded the questionnaire with the permission to a website, and sent research assistants the questionnaires' link. This mail was re-sent to research assistants once in a month, and this process took three months. Due to the lack of data, the researchers went to faculty, gave the questionnaires to research assistants, asked them to fill it, and took those questionnaires back from them.

After the data were collected, the quantitative analyses were applied to them. In order to find out the level of mistreatment research assistants were exposed to and the level of strategies they used to overcome the mistreatment, descriptive statistics (mean, standard deviation, percentage) were used. In order to analyze them, SPSS (Statistical Package for Social Sciences for Windows 15.0) were used.

\section{Results}

In order to give answers to main and sub-problem sentences descriptive analysis, Mann Whitney U and Kruskal Wallis tests were applied to the data collected. Analyses were applied to 198 
Günçavdı, G., \& Polat, S. (2015). Research assistants' perception of mistreatment and the strategies they prefer to overcome this mistreatment. International Journal of Human Sciences, 12(2), 1662-1673. doi: $10.14687 /$ ijhs.v12i2.3496

questionnaires, because among the sent 255 questionnaires 204 were returned and 6 questionnaires were eliminated due to lack of answers or systematic answering.

Firstly, descriptive analysis was applied to measure research assistants' perception of mistreatment and the results are given in Table 1.

Table 1: Results of Descriptive Analysis Related to Research Assistants' Mean Scores of Mistreatment and its SubDimensions

\begin{tabular}{llll}
\hline Dimensions & $\mathbf{n}$ & $\bar{X}$ & Standard Deviation \\
\hline Organizational Mistreatment & 198 & 2,65 & 1,225 \\
Interpersonal Mistreatment & 198 & 2,30 & 0,898 \\
\hline Total & 198 & 2,48 & 1,001 \\
\hline
\end{tabular}

According to Table 1, it is seen that research assistants' level of perception of mistreatment is in the low level $(\bar{X}=2,48)$. Between the sub-dimensions, research assistants level of perception of interpersonal mistreatment is in the low level $(\bar{X}=2,30)$. However, their perception of organizational mistreatment is in the mid-level $(\bar{X}=2,65)$.

In order to analyze whether research assistants' level of perception of mistreatment shows significant difference depending on personal variables, Mann Whitney $U$ and Kruskal Wallis tests were applied to gender, age, tenure and educational status variables. The results showed that research assistants' perception showed significant difference only considering the gender variable. The analysis results are shown in Table 2.

Table 2: The Results of Descriptive Analysis and Mann Whitney U Test according To Gender

\begin{tabular}{lllllllll}
\hline Groups & & $\mathbf{n}$ & $\bar{X}$ & Sd & Mean Rank & $\begin{array}{l}\text { Sum of } \\
\text { Ranks }\end{array}$ & U & p \\
\hline \multirow{2}{*}{ Gender } & Female & 93 & 2,63 & 0,999 & 108,45 & 10086,00 & 4050,00 & 0,038 \\
& Male & 105 & 2,35 & 0,988 & 91,57 & 9615,00 & & \\
\hline
\end{tabular}

The results in Table 2 show that female research assistants' level of perception of mistreatment is in the mid-level $(\bar{X}=2,63)$, while male research assistants' level of perception is in the low level $(\bar{X}=2,35)$. According to the results of Mann Whitney $\mathrm{U}$ test which was applied in order to find out whether the level of perception of mistreatment changes depending on gender within the study group of this research which consists of 105 male and 93 female research 
Günçavdı, G., \& Polat, S. (2015). Research assistants' perception of mistreatment and the strategies they prefer to overcome this mistreatment. International Journal of Human Sciences, 12(2), 1662-1673. doi:10.14687/ijhs.v12i2.3496

assistants, there is a significant difference between the level of perception ( $U=4050,00, p=$ $0,038<0,05)$. The mean scores of research assistants level of perception of mistreatment shows that female research assistants' level of perception $(\bar{X}=2,63)$ is higher than male research assistants' level of perception $(\bar{X}=2,35)$.

With the purpose of analyzing whether research assistants' level of perception of mistreatment shows significant difference depending on organizational variables, Kruskal Wallis test was applied to the faculty where they work, their study areas and the type of staff variables. The results revealed that research assistants' level of perception of mistreatment shows significant difference only depending on the faculty they work. The results of Kruskal Wallis analysis are given in Table 3.

Table 3: The Results of Descriptive Analysis and Kruskal Wallis test according to the Faculty They Work

\begin{tabular}{|c|c|c|c|c|c|c|c|c|c|}
\hline Groups & & $\mathrm{n}$ & $\bar{X}$ & Ss & Mean Rank & sd & $\chi^{2}$ & $\mathrm{p}$ & $\begin{array}{l}\text { Significant } \\
\text { Difference }\end{array}$ \\
\hline \multirow{7}{*}{$\begin{array}{l}\text { The Faculty } \\
\text { They Work }\end{array}$} & E.A.S. & 28 & 3,04 & 1,289 & 118,66 & \multirow{7}{*}{6} & \multirow{7}{*}{34,297} & \multirow{7}{*}{0,000} & \multirow{7}{*}{$\begin{array}{l}\text { E.A.S.-Law, } \\
\text { E.A.S.- } \\
\text { Arts\&Sci., } \\
\text { E.A.S -Tech., } \\
\text { Edu.-Law, } \\
\text { Edu.-Arts\& } \\
\text { Sci.,Commun.- } \\
\text { Law, } \\
\text { Commun.- } \\
\text { Arts\&Sci., } \\
\text { Engineering- } \\
\text { Law, } \\
\text { Engineering- } \\
\text { Arts\&Sci., } \\
\text { Engineering- } \\
\text { Tech. }\end{array}$} \\
\hline & Education & 15 & 2,71 & 0,901 & 107,50 & & & & \\
\hline & Engineering & 76 & 2,71 & 0,914 & 106,80 & & & & \\
\hline & Communication & 15 & 2,54 & 0,802 & 100,70 & & & & \\
\hline & Technology & 13 & 2,05 & 0,856 & 72,00 & & & & \\
\hline & Law & 14 & 1,87 & 0,494 & 62,04 & & & & \\
\hline & Arts and Science & 27 & 1,72 & 0,582 & 51,83 & & & & \\
\hline
\end{tabular}

According to results in Table 3, it is seen that the levels of perception of mistreatment of research assistants who work at Faculty of Economic and Administrative Sciences $(\bar{X}=3,04)$, Faculty of Education ( $\bar{X}=2,71)$, and Faculty of Engineering $(\bar{X}=2,71)$ are mid- level; the levels of perception of mistreatment of research assistants who work at Faculty of Communication $(\bar{X}=2,54)$, Faculty of Technology $(\bar{X}=2,05)$ and Faculty of Law $(\bar{X}=1,87)$ are low-level; the level of perception of mistreatment or research assistants who work at Faculty of Arts and Sciences $(\bar{X}=1,72)$ is quite low.

The results of Kruskal Wallis analysis proved that the variable "faculty they work at" created significant difference among research assistants' levels of perception of mistreatment. $\left(\chi^{2}=34,297, p=0,000<0,05\right)$. Because of the significant difference among groups, multiple comparisons with Mann Whitney $\mathrm{U}$ test were applied. The results of these comparisons have shown that there are significant differences between research assistants' levels of perception of 
Günçavd1, G., \& Polat, S. (2015). Research assistants’ perception of mistreatment and the strategies they prefer to overcome this mistreatment. International Journal of Human Sciences, 12(2), 1662-1673. doi:10.14687/ijhs.v12i2.3496

mistreatment who work at Faculty of Economics and Administrative Sciences $(\bar{X}=3,04)$ and Faculty of Technology $(\bar{X}=2,05)$, Faculty of Law $(\bar{X}=1,87)$ and Faculty of Arts and Sciences $(\bar{X}=1,72)$; Faculty of Education $(\bar{X}=2,71)$ and Faculty of Law $(\bar{X}=1,87)$, Faculty of Arts and Sciences $(\bar{X}=1,72)$; Faculty of Communication $(\bar{X}=2,54)$ and Faculty of Law $(\bar{X}=1,87)$ and Faculty of Arts and Sciences $(\bar{X}=1,72)$; Faculty of Engineering $(\bar{X}=2,71)$ and Faculty of Technology $(\bar{X}=2,05)$, Faculty of Law $(\bar{X}=1,87)$, Faculty of Arts and Sciences $(\bar{X}=1,72)$.

Within this research, after analyzing whether research assistants' level of perception of mistreatment differs significantly depending on personal and organizational variables, the strategies they use to overcome mistreatment were analyzed and descriptive analysis was used for this analysis. The results are given in Table 4.

Table 4: The Results of Descriptive Analysis of Strategies Research Assistants Use to Overcome Mistreatment

\begin{tabular}{llll}
\hline Strategies to Overcome Mistreatment & n & $\bar{X}$ & $\begin{array}{l}\text { Standard } \\
\text { Deviation }\end{array}$ \\
\hline Barriers & 198 & 3,59 & 0,998 \\
Control Others & 198 & 3,02 & 1,077 \\
Control-Self & 198 & 2,43 & 1,024 \\
\hline
\end{tabular}

According to the results in Table 4, research assistants' level of using the strategy of "barriers" is the highest $(\bar{X}=3,59)$, and the strategy "control others" $(\bar{X}=3,02)$ and "controlself' $(\bar{X}=2,43)$ follow it respectively.

\section{Discussion and Conclusion}

The results of this research has shown that research assistants' level of perception of mistreatment is at low-level; their level of perception of organizational mistreatment, which is mistreatment's sub-dimension, is at mid-level and their level of interpersonal mistreatment, which is the other sub-dimension of mistreatment, is at low-level.

In this research, it has been seen that research assistants' level of perception of mistreatment differs significantly only depending on gender out of personal variables, and on the faculty they work at out of organizational variables. According to the variable "gender", female research assistants' level of perception of mistreatment is higher than male research assistants'. This results show similarities to the other research's results(Ayan, 2011; Blase, Blasé\& Du, 2009; Richman, Rospenda, Nawyn, Flaherty, Fendrich, Drum\& Johnson, 1999). However in this 
Günçavd1, G., \& Polat, S. (2015). Research assistants’ perception of mistreatment and the strategies they prefer to overcome this mistreatment. International Journal of Human Sciences, 12(2), 1662-1673. doi:10.14687/ijhs.v12i2.3496

research female research assistants' level of perception of mistreatment is higher than male research assistants', Ocak (2008) found out that male teachers are exposed to mistreatment more frequently than female teachers in his study which was conducted in schools. This difference shows that the perception of level of mistreatment can vary in terms of genders depending on the organizational structure or employees' personal characteristics.

According to variable "the faculty they work at", the highest level of perception of mistreatment belongs to the research assistants who work at Faculty of Economics and Administrative Sciences and the lowest level belongs to the research assistants who work at Faculty of Arts and Sciences. It is possible to say that this situation results from different implementation in different faculties of a university. Also it is known that individuals' level of perception of mistreatment is affected by organizational climate, organizational culture and individuals' personality. So it is necessary to evaluate this situation by taking faculties' climate, culture and research assistants' personalities into consideration.

When looked at the results of analysis related to strategies research assistants use to overcome mistreatment, the highest mean belongs to the strategy "barriers". By looking at this result, it is possible to say that research assistants cannot give voice to their problems easily because they believe if they do that, the results will be worse than what they are faced now.

The results of this study show that research assistants face with mistreatment behaviours which could de-motivate them, even the level of mistreatment they are exposed to is at the lowlevel. Because of the fact that universities are institutions where prospective doctors, engineers, lawyers, teachers, managers, etc. are educated and research assistants are the faculty member which will be teaching courses to them in the future, it is highly important research assistants feel safe and motivated while they undertake their masters' degree or Philosophy of Doctorate. So, it is believed that this study contributed to the Educational Management profession in terms of giving an idea about research assistants' present situation to administrators of universities, faculties and departments.

\section{Suggestions}

The following suggestions can be made by taking this research's findings into consideration. First of all, the implementers should be careful about and sensitive to gender differences, because this research shows that the female research assistants think that they are exposed to mistreatment more than their male co-workers. Also during this research, the 
Günçavd1, G., \& Polat, S. (2015). Research assistants’ perception of mistreatment and the strategies they prefer to overcome this mistreatment. International Journal of Human Sciences, 12(2), 1662-1673. doi:10.14687/ijhs.v12i2.3496

different levels of perception of mistreatment were found among different faculties. It is highly possible that this results from some different implementations among faculties. In order to abolish this situation, some standards can be determined for faculties, even for departments. In addition to these, this research revealed that research assistants cannot voice their problems since they believe if they do, they could face with worse situations. To eliminate this and make research assistants feel safe, the managers should be open to hear complaints and grievance, and they should try to find ways to solve things. Lastly, because of the fact that this study is limited to Kocaeli University, it can be suggested that this research be conducted in other universities to gain more effective and valid results; and also qualitative data can be gathered to interpret the results more efficiently and validly.

\section{References}

Akşit-Aşık, N. (2010). A conceptual evaluation of individual and organizational factors affecting employees' and results of job satisfaction (Çalışanların iş doyumunu etkileyen bireysel ve örgütsel faktörler ile sonuçlarına ilişkin kavramsal bir değerlendirme). Türk İdari Dergisi, 467, 31-51.

Ayan, S. (2011). Mobbing to research assistants at universities: Examples of Gazi, Kocaeli and Cumhuriyet University (Üniversitelerde araştırma görevlilerine yönelik psikolojik taciz: Gazi, Kocaeli ve Cumhuriyet Üniversitesi örneği). Akademik Bakıs Dergisi, 27, 1-18.

Bayar, S. A. \& Bayar, V.(2012). Metaphoric perception of academicians and students to the concept of research assistants (Akademisyen ve öğrencilerin araştırma görevliliğine ilişkin metaforik alg1lar1). Journal of Policy Analysis in Education, 1(1), 26-48.

Blase, J. \& Blase. J. (2006). Teachers' perspectives on principal mistreatment. Teacher Education Quarterly, 33(4), 123-142.

Blase, J. Blase, J.\& Du, F. (2009). Teacher perspectives of school mistreatment: Implications for district level administrators. Journal of Scholarship and Practice, 6 (1), 8-21.

Boroff, K. E.\& Lewin,D. (1997). Loyalty, voice, and intent to exit a union firm: A conceptual and empirical analysis. Industrial and Labor Relations Review, 51, 50-63.

Boswell, W. R.\& Olson-Buchanan, J. B. (2004). Experiencing mistreatment at work: The role of grievance filing, nature of mistreatment, and employee withdrawal. Academy of Management Journal, 47(1),129-139.

Bursch, B, Fried, J.M., Wimmers, P. F., Cook, I. A., Baillie, S., Zackson, H. \& Stuber. M.L. (2013). Relationship between mediacal students perceptions of mistreatment and mistreatment sensitivity.

$<$ http://informahealthcare.com/doi/abs/10.3109/0142159X.2012.733455 > [30th March 2014]

Büyüköztürk, Ş., Kllıç-Çakmak, E., Akgün, Ö. E., Karadeniz, Ş.\& Demirel, F. (2012). Descriptive Surveys. In Scientific research methods(13th ed., pp. 177-183). Ankara: Pegem Akademi. 
Günçavd1, G., \& Polat, S. (2015). Research assistants’ perception of mistreatment and the strategies they prefer to overcome this mistreatment. International Journal of Human Sciences, 12(2), 1662-1673. doi:10.14687/ijhs.v12i2.3496

Cortina, L.M., Magley, V.J., Williams, J. H.\& Langhout. R. D. (2001). Incivility in the workplace: Incidence and impact. Journal of Occupational Health Psychology, 6(1), 64.

Ergöl, Ş., Koç, G., Eroğlu, K.\& Taşkın, L. (2012). Encountered difficuites of female research assistants at domestic and business life in Turkey (Türkiye'deki kadın araşturma görevlilerinin ev ve iş yaşamlarında karşılaştıkları güçlükler). Journal of Higher Education and Science, 2(1), 43-49

Fraenkel, J. R.\& Wallen, N.F. (2006). How to design and evaluate research in education $\left(6^{\text {th }}\right.$ edition). New York: McGraw-Hill International Edition.

Günçavdı, G.\& Polat, S. (2015). Adaptation of Workplace Mistreatment Scale into Turkish (İş Yerinde Kötü Muamele Ölçeği’ni Türkçe'ye uyarlama çalışması). ASOS Journal, 3(10), 123135.

Harlos, K. P.\& Pinder, C.C. (1999). Patterns of organizational injustice: A taxonomy of what employees regard as unjust. In: J. Wagner (Ed.), Advances in qualitative organizational research, Stamford, CT: JAI. 97-125.

Harlos, K. P.\& Axelrod, L.J. (2005). Investigating hospital administrators' experience of workplace mistreatment. Canadian Journal of Behavioural Science, 37(4), 262-272.

Lim, S.\& Cortina, L.M. (2005). Interpersonal mistreatment in the workplace: The interface and impact of general incivility and sexual harassment. Journal of Applied Psychology, 90(3), 483496.

Meares, M.M., Oetzel, J.G., Torres, A., Derkacs, D.\& Ginossar, T. (2004). Employee mistreatment and muted voices in the culturally diverse workplace. Journal of Applied Communication Research, 32(1), 4-27.

Ocak, S. (2008). Teacher's Perceptions Concerning Mobbing (The Sample Of The City Edirne) (Öğretmenlerin duygusal taciz (mobbing)e ilişkin algıları (Edirne ili örneği)). MA. Trakya University, Institution of Social Sciences, Edirne.

Olson-Buchanan, J. B.\& Boswell, W.R. (2009). Mistreatment in the workplace: Prevention and resolution for managers and organizations. Hoboken, New Jersey: Wiley-Blackwell.

Penhaligon, N. L., Louis, W.R. \&Restubog, S.L.D.. (2013). Feeling left out? The mediating role of perceived rejection on workgroup mistreatment and affective,behavioral, and organizational outcomes and the moderating role of organizational norms. Journal of Applied Social Psychology, 43, 480-497.

Read, E.\& Laschinger, H.K. (2013). Correlates of new graduate nurses' experiences of workplace mistreatment. The Journal of Nursing Administration,43(4),221-228.

Rogers, K. A. (1998). Toward an integrative understanding of workplace mistreatment. PhD Dissertation, The University of Guelph, Canada.

Sulea, C., Filipescu, R., Horga, A., Ortan, C.\& Fischmann, G.(2012). Interpersonal mistreatment at work and burnout among teachers. Cognition, Brain, Behaviour. An Interdisciplinary Journal, 16(4), 553-570.

Tor, S.S. (2011). The Demographic Factors, in Organisations, that are Effecting the Job Satisfaction and Productivity: One Exercise of a Company in Food Industry in Karaman. MA. Karamanoğlu Mehmetbey University, Institution of Social Sciences, Karaman.

Wootton, D. (2011). Book review. Human Resource Management,50(1), 163-165. 